\title{
The Forest Conservation in India and the Role of Indian Supreme Court: A Critical Analysis.
}

\author{
Dr. Madhuri Parikh \\ Asst. Professor, Institute of Law, Nirma University, Ahmedabad, Gujarat, India.
}

\begin{abstract}
The current process of industrialization, urbanization and globalization are adversely influencing on the natural resources like land, water, forests etc. There is utmost need to conserve and utilize these resources in a sustainable manner since they are the very basic components of human development. In a developing country like India, the thrust for economic development has put more pressure on the natural resources, particularly the forest resources. The present paper deals with the issue of forest conservation in India with special role of the Supreme Court of India. In India the conservation of forest has been ensured through legislative acts, judicial pronouncements and executive orders. It is a fact that there are number of legislative steps taken to ensure forest conservation in India but the contribution of Indian Supreme Court in this context is unparallel. Since last two decades the Supreme Court of India has been performing the stellar role by taking a Herculean task of comprehensive conservation and protection of forest across the country. It has added a new dimension to environmental scenario in a country. With the help of some cases, it has covered almost all aspects related to forest conservation and other related issues like conservation of biodiversity, national parks etc. The Court has emerged as a lawmaker on forest conservation issues. How far it is correct? What would be the consequences if the same trend persists? This is the focal point of the present paper.
\end{abstract}

Keywords: Forest Conservation, Legislative Measures, The Supreme Court of India

\section{Scope of Study}

The researcher intends to confine the scope of the research to -implementation of forest conservation law in India with critical role of Indian Judiciary, specifically the role of the Supreme Court.

\section{Hypothesis}

The researcher after making survey of literature on the subject has framed following hypothesis:

i. The Indian judiciary has performed a stellar role in the Forest conservation in India.

ii. The judiciary has contributed to the forest conservation in India by widening the scope of locus standi and entertaining Public interest litigation in India, enunciating a web of doctrines and interpreting constitutional law from environmental perspectives.

iii. The provisions of forest laws were mere letters but the judicial interpretation of these laws has given life and blood to them.

iv. The myth created by the black letter law tradition that judges do not make law but merely find it or interpret is not true in the field of environmental law in Indian context specifically in the area of forest conservation.

\section{Research Methodology}

This is a doctrinal study where the researcher is trying to analyze the critical role of Indian judiciary in developing the concept of conservation of forest Resources in India. The study requires in depth study of provisions relating Forest Conservation in Indian Constitution, specific laws related to it, other laws indirectly dealing with forest conservation and various judicial pronouncements on this subject.

The research is based on the secondary data as it is a doctrinal research. The secondary sources of data are books on the subject, articles from various national and international journals, judicial pronouncements, law journals, All India reporters, Supreme Court cases and reports of committees etc. The data collected from these sources have helped in testing the hypothesis.

\section{Introduction}

India, like most developing countries, is faced with the daunting challenge of developing itself rapidly, while at the same time preserving and protecting its environment. Major environmental problems have resulted in India from the use (and more often misuse) of natural resources base. Legislative and regulatory responses to environmental problems have been adopted in India in the eighties and nineties. But the judicial approaches to 
environmental problems which have also followed, have been especially interesting in India for variety of reasons, which are relevant to the challenges facing courts today, in developed and developing countries alike. ${ }^{1}$ In the last thirty years, the government of India has developed a comprehensive structure of policies for conservation of forest and assessment of environmental impacts. Though there are number of laws dealing directly and indirectly with the conservation of forest but the role of judiciary is unparallel in the conservation of forest in India. The present paper first discusses the laws related to forest in India and then it gives a comprehensive analysis of the role of the Supreme Court of India in the conservation of forest in the country.

\section{The Legislative and Executive efforts for the Conservation of Forests in India}

The present legislative measures in India for the conservation of forest have its origin in the British colonial India. The Supreme Legislative Council passed the first Indian Forest Act in 1865. This amounted to the formalisation of the erosion of both forests and the rights of local people to forest produce. The general law related to forests in British India was contained in the Forest Act 1878 and it's amending acts. The Forest Act of 1927 consolidated the pre-existing laws. The territorial jurisdiction was also limited. The legislative framework during the British Raj was heavily oriented towards extraction of forest resources. Forestry was thus production oriented at that time. The Indian Forest Act, 1927 being the product of the British colonial days, reflects the exploitative intentions of colonial feudal society of the time rather than the environmental and ecological interests to preserve the forest. ${ }^{2} 1927$ Act was an industry friendly act and it was responsible for a serious depletion of forest cover in the country. The act drafted with twin object of restricting the use of forest land for a non-forest purposes and preventing the de-reservation of forests that have been reserved under the act of 1927 The Forest Act of 1927 remained in force till 1980.

An attempt to slow down the rapid deforestation and depletion of forest cover taking place in the country was made in 1980 with the enactment of the Forest (Conservation) Act of 1980.. The emphasis was on checking the conversion of forest lands for non-forest purposes. Stringent rules and regulations have been put in the place to govern forest lands for non-forest purposes. Under this act no state government can authorize such conversion without the approval and permission of the central government.

The act does not prohibit the conversion of forest lands for non-forest purposes all it requires is that the central government must permit such a conversion and that the action for which the permission is sought must have the approval of the central government. The act was designed to have a sweeping approach towards issues related to forest conservation and similar issues, proof of this can be found in the wording of the statement and objects and reasons of the act, which reads, "an act to provide for the conservation of forest and for matter connected therewith or ancillary or incidental thereto.

The provisions of the act have also been drawn upon similar lines. Some of the silent features of this act are:

- Restrictions on the use of forests for non-forest purposes

- Restrictions $n$ the dereservation of reserve forests,

- Regulation concerning the diversion of forest lands by way of lease to industries and individuals

- Restriction on the clear felling of trees and

- Constitution of an advisory committee to grant an approval for the conduct of any activity for which an approval of the Central Government is required.

The Provisions restraining clear felling of trees and restriction of the leasing of forest lands to private individuals and industries were brought in by an amendment in 1988, in order to give more teeth to the forest conservation efforts. The act also speaks about the constitution of an advisory committee to advice the Government in matter concerning the grant of an approval under section 2, or any matter connected with the conservation of forests which may be referred to by the Central Government. The composition of this Committee has to be in accordance with the FCA 2003.

\section{The Forest Policies in India}

Forest policies are drafted in India to provide a direction to legislative and executive action with respect to conservation, exploitation and utilisation of forests and forest resources. The first forest Policy in India was framed in 1894. It provided right of the state to exclusive control over forest protection, production and management. This policy was drafted to strengthen the colonial approach to forestry. ${ }^{3}$ This policy was followed by the policy of 1952 . The Policy of 1952 was essentially in continuation of its predecessor. This

\footnotetext{
${ }^{1}$ Dias Ayesha., Judicial Activism in Development and Enforcement of Environmental Law: Some Compartive Insights from The Indian Experience. (6J.Envit. L. 1994, p.243)

${ }^{2}$ Leelakrishnan P, Environmental Case Law Book, ed. $3^{\text {rd }}, 2003$, lexis Nexis Butterworths.

${ }^{3}$ This policy was drafted on the advice of the German agriculturist Volcker. Commercial production of the timber was the main thrust of the policy. Acquisition of wood for meeting the defence requirements of the Imperial army as well as for other purposes, such as the construction of railways et al was the main purpose of the policy.
} 
policy, too, envisaged forest protection, production and management. ${ }^{4}$ The next Forest Policy was framed in 1988. This policy was a "paradigm shift vis-à-vis the earlier two policies." This was less user-oriented, and focused more on the ecological forests and the importance of their conservation and less on their exploitations. ${ }^{6}$ The policy of 1988 was formulated with the objective of ensuring environmental stability and maintenance of ecological balance. ${ }^{7}$ The policy of 1988 gave incentives to panchayats, local communities and individuals to participate in a forestation, social forestry and farm forestry programmes. For this purpose National Westland Development Boards (NWBD) were set up by the government. But they failed to achieve people's participation in forestation programme. Then to give momentum to people's participation Joint Forest Management (JFM) programme was initiated. Forest Protection Committees (FPC) were also set with the same goal.

The close analysis of legislative efforts and policy measures for the protection of forest resources in India indicates that the web of legal and policy measures is weaved neatly but the problem lies at the time of implementation of this policies. The problems implementing India's forest policies are generally caused by three factors-they tend to conflict with statutes, development initiatives such as dams and other projects, and human activities which generally bad to the destruction of forests. ${ }^{8}$ The ban on the assignments or lease of the forest land to people or institution which are not wholly owned by the Government is in conflict with the permission in the Forest Policy which speaks about participatory management of forests. ${ }^{9}$ The Conflict between the development goals and conservation of resources had reached to its zenith in 1980s and 1990s. At this juncture the judiciary had played a remarkable role in India. The Supreme Court's intervention in forest issues in the mid 1990s happened at a time when neither the Central nor the State Government showed much interest in forest conservation related issues.

The Ministry of Forest and Environment [MOEF] was viewed generally as a soft regulatory hurdle which needed to be crossed before any diversion of forest land. The Supreme Court's intervention changed the situation. The fact that many decisions of the MOEF were subject to final approval from the Supreme Court led to a relatively more detailed appraisal of projects.

The Central Empowered Committee set up by MOEF on the direction of the Supreme Court provided an avenue for grievances redressal which concerned individuals and groups could approach directly without approaching the Supreme Court first. This in a way provided effective access to justice for many interested in protecting India's natural environment. The decision to stop Kundermukh Iron ore company Ltd. from mining in the ecologically fragile Western Ghats during the early part of the present decade was a hallmark of judicial interest and commitment to forest conservation.

\footnotetext{
${ }^{4}$ The policy of 1952 was framed on the basis of six paramount requirements of the country namely:

1. The need for developing a system of balanced and complementary land use,

2. The need for checking (i) the denudation of mountains, (ii) the erosion in the plains and (iii) the invasion of sea sands on coastal tracts and the shifting of sand dunes,

3. The need for establishing tree-lands,

4. The need for increasing supplies of grazing, small wood for agricultural implements and firewood,

5. The need for a sustained supply of timber and other forest procedure, and

6. The need for realization of maximum annual revenue.

${ }^{5}$ Upadhyay, S. and Upadhyay, V., Forest laws, Wildlife and the Environment, Vol. I, Lexis Nexis Butterworths Publications, $1{ }^{\text {st }}$ Edn, 2002 , New Delhi, at p.28.

${ }^{6}$ Ibid.

${ }^{7}$ The silent features of this forest policy are:

1. Maintenance of environmental stability through preservation and restoration of the ecological balance.

2. Conservation of natural heritage of the country by preserving the remaining natural heritage of the country by preserving the remaining natural forest and protecting the vast genetic resources to maintain biological diversity.

3. Checking soil erosion and denudation in the catchment areas for soil and water conservation irrigation floods, droughts and for the retardation of siltation of reservoirs.

4. Checking the extension of sand dunes in deserts areas and along coastal track.

5. Increasing forest cover through massive afforestation and social forestry programmes.

6. Meeting the basic requirements of the people for fuel and fodder.

7. Encouraging efficient utilization of forest product and maximizing substitutions of wood.

8. Creating a massive people's movement with involvement of women for achieving these objectives and to minimize pressure on existing forests. (See, National Forest Policy 1988, Ministry of Environment and Forests New Delhi. (1988) Para 2.1)
}

\footnotetext{
${ }^{8}$ For example, Provisions of the National forest policy of 1988 contradict with the provisions of the Forest Act of 1980 . A prohibition on the plantation of horticultural trees and medicinal plants on forest lands without the prior permission of the government of India in the FCA, 1980 gives rise to a situation in which all usufruct trees are to be limited within forest land, and is in conflict with one of the basic objective of the policy of 1988 which envisages increasing the productivity of forests to meet national needs.

${ }^{9}$ Divan, S., and Rosencranz, Environmental Law and Policy in India, Oxford University Press, $2^{\text {nd }}$ Edn. ,2004, New Delhi at p. 293.
} 


\section{The Role of the Supreme Court of India in Forest Conservation}

The judiciary played an important role in protecting forests and wildlife, by leaving the core areas uncovered by the law as appropriate for legislative action than for judicial formulation. Besides, emphasising the significance of forests, the courts endeavoured to protect the rights of persons affected by development projects and tribal people, who form part of the forest environment. Relying on the 'public trust doctrine' to protect and preserve forest and natural resources they tried to enforce the concept of sustainable development to solve the environment-development dilemma and upheld the controls and exploitation of forest resources. ${ }^{10}$

The role of the Supreme Court of India needs special reference in developing the jurisprudence for forest conservation in India. The independent judiciary embedded with the power of judicial review has performed a stellar role in the conservation of Forest and wildlife in India. The expansion of the locus standi has given momentum to judicial activism in the development of environmental jurisprudence in India.

\section{PIL: an Effective Tool for the Forest Conservation}

Through the tool of PIL (Public Interest Litigation) the Supreme Court had dealt with variety of issues related to conservation of forest, preservation and protection of wildlife ${ }^{11}$, protecting the rights of tribal people and thus balancing the symbiotic relationship between the forest dwellers and the goal of forest conservation ${ }^{12}$. The court has also addressed the issues of balancing the right to freedom of trade and business and the conservation of forest and wildlife ${ }^{13}$ and issues related to biodiversity ${ }^{14}$. With the help of PIL the Supreme Court has interpreted the provisions of the FCA, 1980.

\section{Interpretation and Implementation of Forest Act, 1980 by the Supreme Court}

The Supreme Court has interpreted and enforced the provisions of Forest Conservation Act 1980 strictly in T.N.Godavarman Thirumalkpad v. Union of India ${ }^{15}$. The Court issued sweeping directives to enforce the $\mathrm{FCA}^{16}$. All wood based industries were closed and an embargo was imposed on the exploitation of forest and forest product. The Court also created Central and State committees to enforce the directions it issued in this case. The court recognized that FCA was enacted with a view to check ecological imbalance caused by rapid deforestation. The court also defined the word forest used in the FCA.

The Court said the provisions of the act must apply to all the forests irrespective of the ownership or classification thereof.

"The word forest must be understood according to its dictionary meaning. This description covers all statutory recognized forest, whether designated as reserved, protected or otherwise for the purposes of s.2 (I). The word forest will not only include forest as understood in the dictionary sense, but also any area recorded as forest in the Government record irrespective of ownership."

The Court further said any activity going on in any forest in any state of the country which is a nonforest activity is in isolation of the act and has to cease immediately. As a result, all mining, quarrying activities were prohibited in the forest. Wood based industries such as saw mills were also in violation of the Act, it was held. A complete ban was enforced on the felling of trees in all forests, and felling and logging could be carried out only if they are in accordance with the working plans of the State Government only.

The Courts all over India have followed the Principles laid down by the Supreme Court in Godavarman ${ }^{17}$ cases $^{18}$. Shree Bhagawati Tea Estates v. Government of India ${ }^{19}$ the Supreme Court examined a number of issues with respect to the FCA. Firstly, the court looked at the Kerala Private Forests (vesting and Assignment) Act 1971. This act was part of the agrarian reform of the Kerala Government and it sought to acquire private forest lands for this purpose. This acquired land was then to be distributed amongst landless peasants. The petitioner challenged this act by saying that it violated the provisions of the FCA. It was contended that this acquisition for agricultural purpose would mean clearing of forests on such land, and this was not permissible without the approval of the central government. It was also suggested that the FCA prohibits the leasing of forest land to private and industries or individuals and therefore, the acquired land could not be distributed to the landless.

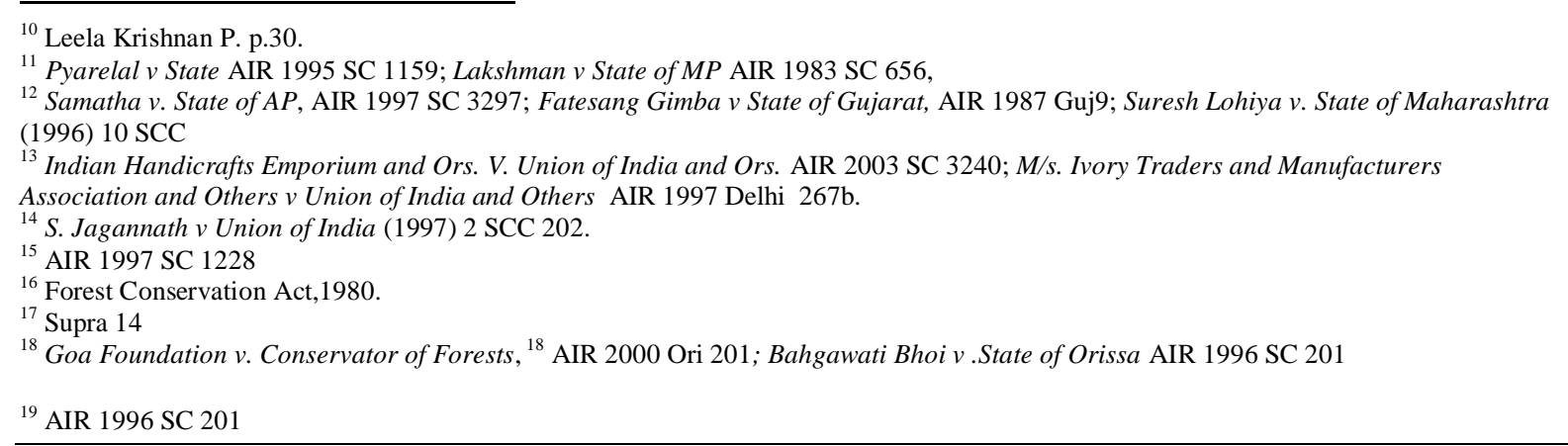


The Supreme Court dismissed these contentions and stated that the FCA does not envisage a complete ban; only approval of the Central Government is required.

In this case the Supreme Court while upholding the legality of the Kerala Private Forests act, reconciled with the need to conserve forests with the need to address the livelihood concerns of the poor and the marginalized.

The Court had also confronted with the issues of mining activities in the forest areas. The court had clearly laid down prohibition of mining activities in the forest areas. ${ }^{20}$ The Supreme Court made it categorically clear that renewal of mining licence after FCA came into force can be made only on getting prior permission from the Central Government ${ }^{21}$. The Supreme Court observed ${ }^{22}$

"the primary duty was to the community and that duty took precedence, in our opinion, in these cases. The obligation to the society must predominate over the obligation to the individuals."

The Court had firmly disallowed the non-forest activities and granting of lease for non forest activities in forests. Renewal of stone crushing lease without prior permission of the from the Central Government ${ }^{23}$ was $^{2}$ considered a serious breach of duty in the case Dhirendra agrawal $v$. State of Bihar. ${ }^{24}$ The use of forest land for non forest purpose was clearly denied by the court in the case of State of Bihar v. Banshi Ram Modi. ${ }^{25}$ Similarly excavations of iron ore ${ }^{26}$ and tourism ${ }^{27}$ in forest were highly criticised by the Supreme Court.

\section{The International Conventions and the Judicial Response}

The Supreme Court has implemented the principles of Sustainable development for the conservation of forest and wild life resources through the tool of PIL. In State of Himachal Pradesh v. Ganesh Wood Products ${ }^{28}$ the Supreme Court dealt with the main issue of indiscriminate felling of Khair trees for katha industries. The Court referred to the principles of intergenerational equity and implemented the concept of sustainable development. The Supreme Court commented ${ }^{29}$, "After all, the present generation has no right to deplete all the existing forests and leave nothing for the next and future generations... The obligation of sustainable development requires that a proper assessment should be made of the forest wealth and the establishment of industries based on forest produce should not only be restricted accordingly but their working should also be monitored closely to ensure that the required balance is not disturbed".

In M.C. Mehta v Kamal Nath and Others ${ }^{30}$ the Supreme Court felt the need to strike a balance between public utility as well as necessity to maintain the environment. The Court observed ${ }^{31}$, "Sustainable development is essentially a policy and strategy for continued economic and social development without detriment to the environment and natural resources on the quality of which continued activity and further development depend. Therefore, while thinking of the developmental measures the needs of the present and ability of the future to meet its own needs and requirements have to be kept in view. While thinking of the present, the future should not be forgotten. We owe a duty to future generations and for a bright today, bleak tomorrow cannot be countenanced. We must learn from our experiences of past to make both the present and the future brighter. We learn from our experiences, mistakes from the past, so that they can be rectified for better present and future. It cannot be lost sight of that while today is yesterday's tomorrow, it is tomorrow's yesterday."

\section{Contribution of the Supreme Court through Godavarman Case}

The Godavarman case represents perhaps the single largest intervention by any court in the world on any single issue. It is presently in its fifteenth year and is now heard two days a week by two separate benches of the court. In the last 15 years over 15 judges heard the cases at different times. It represents in all its myriad form, a unique judicial effort to deal with the deforestation and forest governance issues. It has without doubt given the subject of forest some degree of seriousness in the national policy debate. ${ }^{32}$

The genesis of the Godavarman case was a result of the non responsiveness of various State Governments to the issue of forest conservation. The Godavarman Case concerns, primarily the Forest (Conservation) Act, 1980, together with the National Forest Policy, 1988. However the case progressed, and

\footnotetext{
${ }^{20}$ Rural Litigation and Environment Kendra v.State of Uttar Pradesh AIR 1988 SC 2187, Tarun Bharat Sangh Alwar v. Union of India AIR1992 SC 514.

${ }^{21}$ Ambika Quarry Works $v$ The State of Gujarat, AIR 1987 SC 1073

$22 \mathrm{Id}, \mathrm{p} 1076$.

${ }^{23}$ It is mandatory under section 2 of FCA, 1980.

${ }^{24}$ AIR 1993 Pat 109

${ }^{25}$ AIR 1985 SC 814

${ }^{26}$ B V Joshi v State of Andhra Pradesh AIR 1989 AP 122

${ }^{27}$ Union of India v Kamath Holiday resorts Pvt. Ltd. AIR 1996 SC 1040

28 (1995) 6 SCC 363

29 Ibid

${ }^{30}$ (1997) 1 SCC 388

${ }^{31}$ Ibid

${ }^{32}$ Dutta , R. and Yadav B., Supreme Court on Forest Conservation, Universal Law Publishing co. New Delhi., Ed. 3rdp XIV.
} 
diverse issues were raised, the court could not limit itself to the narrow confines of the FCA of 1980. At numerous occasions, issues concerning wildlife protection were raised. Most of these were concerned with the protection of National parks and Sanctuaries. The various orders in the Godavarman Case have touched each and every aspect related to forest and wild life conservation in country. The court had tried to fill the gap between the law on forest conservation and its implementation.

In T.N. Godavarman Thirumulkpad v Union of India ${ }^{33}$ the Court issued sweeping directives to enforce the Forest Conservation Act, $1980 .^{34}$ The Court ordered to close wood based industries and on exploitation of forest and forest product. The Court also created Central and State committees to enforce the directions it issued in this case. The court recognized that FCA was enacted with a view o check ecological imbalance caused by rapid deforestation. It was clearly stated by the Court that the provisions of the act must apply to all the forests irrespective of the ownership or classification thereof.

The Supreme Court has touched wide range of issues related to forest conservation through the different orders in Godavarman case. Through this case the court has addressed the issues like defining the term forest and implementation of Forest Conservation Act, $1980^{35}$, Constitution of High Power Committee to oversee implementation of Court's orders in Northern Eastern State $^{36}$, encroachment of forest land ${ }^{37}$, constitution of Arunachal Pradesh Forest Protection Authority ${ }^{38}$, Formation of State and central level Authorities under the Environment ( Protection) Act ${ }^{39}$, constitution of Central Empowered Committee ${ }^{40}$, Forest advisory committee, the issues related to regulation of non forest use of forest land and protection of wild life and sanctuaries and national parks throughout the country.

The constitution of Central Empowered Committee is the positive step taken by the Court to preserve forest resources. Any individual having grievances against any steps taken by Government or any other authority in purported compliance with the order passed by the Supreme Court will be at liberty to move the committee seeking suitable relief. Any application which cannot be disposed off by the Committee can be referred to the Supreme Court.

Forest conservation law in India is not only impacted by the Godavarman case alone but also by the decisions of the Supreme Court in the Centre for Environmental Law, WWF-India v. Union of India ${ }^{41}$ which is related to protection of National Parks and Sanctuaries. Although the principle concern of the case is related to the issues of settlement of rights in National parks and Sanctuaries, yet its scope is much beyond this issue. The most significant was the order of 13-11-2000, wherein the Supreme Court through interim order restrained all State government from dereserving National Parks, sanctuaries and Forests.

The contributions of the judgments in these cases have made unique contribution to the movement for conservation of forest in India. The Godavarman case is undoubtedly one of the classic cases for the study of continuing mandamuses and the scope of Public Interest Litigation.

\section{Conclusion}

The Judiciary has contributed to the development of forest law in India by widening the scope of locus standi and entertaining Public interest litigation in India, enunciating a web of doctrines and interpreting Constitutional law from environmental perspectives. It is true. The provisions of Forest law were mere letters but the judicial interpretation has given life and blood to them. The myth created by the black letter law tradition that judges do not make law but merely find it or interpret is not true in the field of environmental law in Indian context. They do make law. The Godavarman case and Centre for Environmental Law, WWF- India v. Union of India are the best examples of it. The Supreme Court has tried to fill the gap between law and its implementation by creative interpretation of forest laws in India. The judiciary has performed the role of law maker and established various committees and empowered them to enforce the provisions of forest laws. The thrust for economic development and the need for protection of forest resources has put a challenge for the developing country like India. In such situation the apex Court has tried to strike a balance by giving green signals to big projects and dams in the interest of the development of the county but at same time the efforts have been made by the court to take care of the environment impact assessment of these projects and protection of the rights of the forest dwellers and taking care of their rehabilitation and other issues.

On the basis of the analysis of the cases discussed in the present research paper it can be concluded that the judges do make law. The judicial law -making is the part of the judicial process. Today, it is no longer a

\footnotetext{
${ }^{33}$ AIR 1996 SC 1228

${ }^{34}$ Divan, S. and A. Rosencranz, environmental Law and Policy in India, Oxford University Press, $2^{\text {nd }}$ Edn. ,2004,New Delhi, at p. 294.

${ }^{35}$ Supra 33

${ }^{36}$ Order dated 04-03-1997.

${ }^{37}$ Order dated 28-07-1998

${ }^{38}$ Order dated 29-10-1998

${ }^{39}$ Order dated 13-04-2000

${ }^{40}$ Order dated 18-02-2002.

${ }^{41}$ W.P.337 of 1995.
} 
matter of doubt that the substantial volumes of law governing the lives of citizens and regulating the functions of the State flows from the decisions of the Superior Court. The Supreme Court's effort in the conservation of the forest resources is unique.

\section{References}

[1]. A Usha(edited), Endangered species and forests: Legal Perspectives, 2007, Amicus Books, the Icfai University Press

[2]. Abraham,C.M.; Environmental Jurisprudence in India, 1999. Kluwer Law International

[3]. Bakshi, P.M., Public Interest Litigation. , 2004, Ashoka Law House.

[4]. Bharti, H.K. and Dubey, B.K.; Manuel of Environment and Pollution Laws, ed. $1^{\text {st }}, 2010$, Wadhwa and Company, Indore

[5]. Chandra Pal., Environment Pollution and Development: Environmental Pollution Policy and Judiciary. 1999, Mittal Publications, New Delhi.

[6]. Chauhan ,J.K., Relations in Working of Legislature, Executive and Judiciary: An introspection and Prospective Vision, 2007,Allhabad law Agency.

[7]. Desai, Ashok. A., Environmental Jurisprudence, 2002, Modern Law House

[8]. Deswal, S., Deswal, A., A basic course in Environmental Studies., 2004, Dhanpat Rai and Co. New Delhi.

[9]. Divan, Shyam. \& Rosencranz, Armin., Environmental law and policy in India., 2001.,Oxford University Press.

[10]. Diwan ,Paras, Diwan, Peeyudhi., (edited), Environment Administration, law and Judical Atitude, 1997, Deep and Deep Publication s

[11]. Dubey,B.K.,Bharti, H.K., Manual of Environmental Laws, 2010, Wadhwa \& Company, Indore

[12]. Dutta, Rutwick., Yadav, Bhupendra., 2011, Supreme Court on Forest Conservation, Universal Law Publishing.

[13]. Thakur, Kailash., Environmental Protection law and policy in India, 2003, Deep \& Deep Publication Pvt. Ltd.

[14]. P. Leelakrishanan., Environmental law case book, 2004, Butterworths India, New Delhi

[15]. Sathe. S.P.; Judicial Activism in India, Ed. $2^{\text {nd }}, 2003$, Oxford University Press. 